\title{
Factors affecting the uterine inflammatory response to semen
}

\author{
Sandro Barbacini and Edward L. Squires
}

Select Breeders Services Italia, San Daniele Po (CR), Italy and University of Kentucky Maxwell H. Gluck Equine Research Center, Lexington, Kentucky USA

\begin{abstract}
This manuscript addresses some of the factors that affect the severity of the inflammatory response after breeding. At the time of breeding or insemination the uterus is exposed to seminal components, bacteria and debris. This results in an inflammatory response characterized by the influx of polymorphonuclear neutrophils (PMN) into the uterine lumen. A review of the recent literature was carried out in order to take stock of the situation on how age of mare and reproductive status, seminal plasma, insemination dose and site of insemination, type of semen and number and timing of insemination influence this phenomenon. The comparison of the data shown in the studies demonstrates that at least in normal mares there is no disadvantage to insemination more than once in a cycle and if semen is available for two inseminations, then the management of the mares with frozen semen can be similar to that used for cooled semen or those bred naturally.
\end{abstract}

Keywords: semen / endometritis / mare / reproduction

\section{Welche Faktoren beeinflussen die uterine entzündliche Reaktion auf das Sperma?}

In diesem Artikel werden einige Faktoren aufgeführt, die den Schweregrad der entzündlichen Reaktion des Endometriums nach der Bedeckung beeinflussen. Durch den Deckakt oder die Insemination wird der Uterus den Komponenten des Spermas, Bakterien und Verunreinigungen ausgesetzt. Das Ergebnis ist eine entzündliche Reaktion, die durch Einwanderung neutrophiler Granulozyten in das Lumen charakterisiert ist. Anhand aktueller Literatur wird eine Bestandsaufnahme erstellt, inwieweit das Alter und der Reproduktionsstatus der Stute, das Seminalplasma, die Menge und Lokalisation der Insemination, Spermaart sowie Anzahl und Wahl des Zeitpunktes der Insemination dieses Phänomen beeinflussen. Vergleicht man die Ergebnisse der Studien, zeigt sich, dass sich zumindest bei der normalen Stute durch die mehrmalig in einem Zyklus erfolgte Insemination kein Nachteil ergibt. Auch in dem Fall, dass Sperma für zwei Inseminationen zur Verfügung steht, ist das Management der mit gefrorenem Sperma besamten Stuten ähnlich dem nach Verwendung von gekühltem Sperma oder nach Natursprung.

Schlüsselwörter: Sperma / Endometritus / Stute / Reproduktion

\section{Introduction}

At the time of breeding or insemination the uterus is exposed to seminal components, bacteria and debris. This results in an inflammatory response characterized by the influx of polymorphonuclear neutrophils (PMN) into the uterine lumen. The purpose of the inflammation is to clear from the uterus defective and excess sperm, and other contaminating agents. The influx of PMNs into the uterine lumen results in phagocytosis of sperm, bacteria and release of prostaglandin, which causes uterine contractions. This inflammation is quickly cleared from the uterus within 36 hours. In fact, in most mares that are resistant to delayed post breeding endometritis, the uterus is clear of fluid by 24 hours with the peak of PMNs and uterine fluid occurring at 12 hours after insemination. It has often been stated that insemination of mares with frozen semen results in a greater inflammatory response However there are limited data on the response of the mare's uterus to various types of semen. This manuscript addresses some of the factors that affect the severity of the inflammatory response after breeding.

\section{Age of Mare and Reproductive Status}

Barbacini at al. in 2003 reported that 17\% of the mares 3 to 9 years of age had uterine fluid after insemination with frozen thawed semen versus $28 \%$ of the mares 10 to 16 years of age and $68 \%$ of the mares greater than 16 years of age. The presence of fluid in older mares dramatically decreased pregnancy rate. In contrast when infertile or aged mares were excluded from this study, the incidence of fluid after insemination with frozen thawed semen was $16 \%$, which is identical to the report of Watson at al. (2001) for mares naturally mated. This is in contrast to Guvenc et al. 2004, who compared uterine fluid accumulations in young versus old mares inseminated with frozen semen. They reported that the rate of inflammation did not differ between the two groups of mares. Barbacini et al. 2003, in a retrospective study of mares inseminated with frozen semen, reported that barren mares had more uterine fluid (38\%) versus maiden mares (19.7\%) and foaling mares $(17.8 \%)$. The presence of uterine fluid after insemination of frozen semen decreased pregnancy rates in the foaling mares (44\% vs 68\%). Recently, Barbacini et al. 2008 reported higher pregnancy rates, for mares less than 16 yr old versus greater than $16 \mathrm{yr}$, when inseminated with frozen semen. Treatment of mares with oxytocin or uterine lavage improved pregnancy rates after insemination with frozen semen. Thus the age of the mare and reproductive status of the mare at the time of breeding has an influence on the amount of uterine fluid after breeding. Obviously mares in these two categories( barren and old) would need to be treated for fluid accumulations in order to improve fertility. 


\section{Role of Seminal Plasma}

One of the reasons it has been suggested that frozen thawed semen results in a greater inflammatory response is the fact that the majority of seminal plasma is removed from semen prior to freezing. Troedsson et al. 2002 demonstrated that the addition of seminal plasma in vitro, reduced the binding of the neutrophils to sperm. The same investigators further demonstrated that seminal plasma selectively reduces the binding of live sperm to PMN while enhancing the binding of PMN to dead sperm. They also demonstrated that if insemination was made into an inflamed uterus, the complete remo$\mathrm{val}$ of seminal plasma from the inseminate resulted in a very low pregnancy rate. These studies together emphasize the role of seminal plasma in modulating the post- breeding inflammation. However, with frozen semen approximate 5\% seminal plasma is still remaining after processing for freezing and this may be enough seminal plasma to modulate the inflammatory response. This would suggest that the inflammatory response after insemination or frozen thawed semen may be more a function of sperm number and concentration versus the lack of seminal plasma.

\section{Insemination Dose and Site of Insemination}

Katila (2005) reported that insemination of high sperm numbers in a small volume resulted in greater inflammatory response then low sperm numbers in high volume. Guvenc et al. (2005) conducted a study to compare the inflammatory response of mares inseminated with low or high numbers of sperm of frozen semen into the uterine horn or uterine body. Thirty two mares were inseminated with either 20 million or 200 million sperm in $.5 \mathrm{ml}$ in uterine body versus 20 million or 200 million in .5 ML in the uterine horn. They sampled the mares for presence of uterine fluid and numbers of PMN, 24 hours after insemination. The treatment group inseminated with 20 million sperm into the uterine horn had less fluid than all other groups whereas the number of PMNs was the same among the four groups. They concluded that the insemination of low numbers of sperm into the uterine horn was the preferred method for minimizing the inflammatory response. More importantly they concluded that deep horn insemination did not increase the risk of post- breeding endometritis. Sieme et al. (2004) reported no difference in uterine fluid accumulation between mares inseminated with a hysteroscope versus deep horn insemination using a flexible catheter. Per cycle pregnancy rates of mares inseminated with frozen semen was lower than that for mares inseminated with fresh semen, in problem mares but not in normal mares. He concluded that the lower pregnancy rates in problem mares with frozen semen were not due to a difference in the inflammatory response. Others have provided information that the amount of inflammation is dependent upon sperm concentration, with higher concentrations causing a greater inflammatory response. More recently, Fiala et al. (2007) determined the influence of sperm concentration on the intensity of uterine inflammation at 2, 4 and 24 hours after insemination of cooled semen. Mares were inseminated with semen diluted to 5,25 or 50 million per milliliter suspended in $17 \mathrm{ml}$ of skim-milk extender $+3 \mathrm{ml}$ of seminal plasma. Controls included a group of non-inseminated mares and those inseminated with either skim milk or seminal plasma alone. Seminal plasma increased uterine inflammation relative to controls at two hours and skim milk increased uterine inflammation relative to controls at four and 24 hours. Inflammation was dependent upon sperm concentration with a higher concentration causing the greatest inflammatory response.

\section{Type of Semen}

Although it is often stated that insemination of mares with frozen thawed semen results in a greater inflammatory response, studies in which mares are inseminated with various types of semen and the inflammatory response determine are quite limited. Kotilainen et al. (1994) compared the inflammatory reaction induced in the uterus by insemination with fresh and frozen semen. They used 11 groups, 6 to 8 mares per group over two breeding seasons. They examined whether components of the extender, enzymes from damage sperm, or high concentrations in low volumes were the primary cause of uterine inflammation. Forty seven cycling, nonlactating mares and three stallions were used in the study. Six hours after the treatment, mares were palpated and ultrasounded for uterine fluid. PMN from fluid recovered from the mare's uterus was counted. The least amount of PMN in the uterus was caused by infusion of PBS, supernant from centrifuging frozen semen, skim milk extender, and egg yolk extender. Interestingly, the number of PMN was similar for mares inseminated with frozen semen, frozen semen plus seminal plasma and concentrated fresh semen. They concluded that the components of the extenders (Skim milk, Egg yolk, glycerol) were not responsible for the inflammatory response and neither was the enzymes released from the frozen/ thawed sperm. Highly concentrated sperm whether fresh or frozen/thawed caused the greatest inflammatory response. Diluting the frozen/thawed sperm in $30 \mathrm{ml}$ of skim milk extender decreased the inflammatory response. Fertility trails are needed where frozen semen is diluted in extender in order to decrease the concentration and increase the volume.

Recently data (unpublished) were made available from two affiliate labs of Select Breeder Service. These two labs froze semen under the same protocol and provided data where mares were inseminated with fresh, $24 \mathrm{hr}$ cooled, or frozen semen. Unfortunately the numbers of mares in each semen group were not equal and mares were only inseminated with one semen type. However, of 76 mares bred with fresh semen, $72 \%$ were pregnant on that cycle, and $28 \%$ had uterine fluid $24 \mathrm{hr}$ after breeding. This compares to 11 of 11 becoming pregnant with cooled semen and $36 \%$ having uterine fluid and 61 of 89 bred with frozen semen (69\%) becoming pregnant after one cycle and $11 \%$ of mares having uterine fluid. Since this are field data it is hard to make statistical comparisons but it seems safe to say that frozen semen did not decrease pregnancy rates or increase the incidence of uterine fluid $24 \mathrm{hr}$ after insemination

\section{Number and Timing of Insemination}

Depending on the quantity of semen made available, mares are inseminated either once or twice during the cycle. By inseminating twice during the cycle mares only need to be examined with ultrasound once per day similar to the manage- 
ment of mares inseminated with cooled semen. However there are two reasons why breeders choose to breed only once during the cycle: cost of the semen and fear of a greater inflammatory response with two inseminations with frozen semen in one cycle. Numerous studies have shown that the fertility of mares inseminated twice during the cycle with frozen semen was similar to that of mares inseminated once (Barbacini et al. 2008, Loomis and Squires (2005). Based on several hundreds of mares, Loomis and Squires (2005) reported a $51.5 \%$ and $51.7 \%$ per cycle for mares bred once versus two or more times in the cycle. In another group of mares, in the same study, pregnancy rates per cycle were also similar for once versus two time $\mathrm{Al}$ ( $47 \%$ vs. $46 \%$ ). Also the incidence of uterine fluid post-breeding was similar for the two $\mathrm{Al}$ groups (one-23\%; twice-23\%). These results are supportive of others that have reported higher pregnancy rates with 2 inseminations per cycle (Samper et al. 2005). It is common in France (Vidament et al. 1997) to inseminate mares with frozen semen daily after administration of an ovulatory agent and until ovulation. Metcalf (2000) conducted a study to determine the fertility of the second dose of semen in mares inseminated twice during the cycle with frozen semen. Thirty six to $40 \mathrm{hr}$ after hCG, mares were inseminated with frozen semen from stallion $A$ then $6-10 \mathrm{hr}$ after the first insemination they were inseminated with frozen semen from stallion $B$. Parentage of the foals was determined by DNA. Eight of 11 were pregnant after once cycle and one mare was pregnant after 3 cycles of breeding. The sire of the foals was stallion A in 4 cases and stallion B in 5 cases. She concluded that postbreeding endometritis from the first $\mathrm{Al}$ was not detrimental to the fertility of a second dose.

The uterine response to multiple inseminations was studied further by Card et al. 2004. Thirty-three mares were assigned to one of three groups: nonbred, single insemination or two inseminationwith frozen semen. Sample of uterine fluid were collected at 24, 48, 72, 96 (groups 1 and 2) and $24 \mathrm{hr}$ (groups 3) after insemination Scores were developed for debri, bacteria and PMN in the uterine flushing. Within groups 1 and 2 there no time effects for these parameters suggesting sampling between 24 and $96 \mathrm{hr}$ gave similar results. Bacterial scores, debris and numbers of PMN were similar for mares inseminated once versus twice in a cycle.

These studies combined demonstrate that at least in normal mares there is no disadvantage to inseminationmore than once in a cycle and if semen is available for two inseminations then the management of the mares with frozen semen can be similar to that used for cooled semen or those bred naturally.

\section{References}

Barbacini S., Necchi D., Zavaglia G. and Squires E. L. (2003) Retrospective study of the incidence of postinsemination uterine fluid in mares inseminated with frozen/thawed semen. Equine Vet. Sci. 23, 493-496
Barbacini S., Necchi D., Postinger F. and Squires E. L. (2008) What to expect when barren mares are inseminated with frozen-thawed semen. Proc 54th Am. Assoc. Equine Pract. 54, 1-3

Card C., Carley S., Green J. and Chirino-Trejo M. (2004) Endometrial cytology in mares bred with frozen semen. Am. Assoc. Equine Pract. Proceedings 50, 505-509

Fiala S. M., Pimentel C. A., Mattos A. L. G., Gregory R. M. and Mattos R. C. (2007) Effect of sperm numbers and concentration on sperm transport and uterine inflammatory response in the mare. Theriogenology 67, 556-562

Guvenc K., Reilas T. and Katila T. (2005) Effect of insemination dose and site on uterine inflammatory response of mares. Theriogenology 63, 2504-2512

Katila T. (2005) Effect of the inseminate and the site of insemination on the uterus and pregnancy rates of mares. Anim. Reprod. Sci. $89,31-38$

Kotilainen T., Huhtinen M. and Katilia T. (1994) Sperm-induced leukocytosis in the equine uterus. Theriogenology 41, 629-636

Loomis P. R. and Squires E. L. (2005) Frozen semen management in equine breeding programs. Theriogenology 64, 480-491

Metcalf E. S. (2000) The effect of postinsemination endometritis on fertility of frozen stallion semen. Am. Assoc. Equine Pract. Proceedings. 46, 330-331

Samper J. C., Vidament M., Katila T., Newcombe J., Estrada A. and Sargeant J. (2002) Analysis of some factors associated with pregnancy rates of frozen semen: a multi-center study. Theriogenology $58,647-650$

Sieme H., Bonk A., Hamann H., Klug K. and Katila T. (2004) Effect of different insemination techniques and sperm does on fertility of normal mares and mares with abnormal reproductive history. Theriogenology 62, 915-928

Troedsson M. H. T., Loset K., Alghamdi A. M., Dahms B. and Crabo B. G. (2001) Interaction between equine semen and the endometrium: the inflammatory response to semen. Anim. Reprod. Scie. 68, 273-278

Troedsson M. H. T., Alghamdi A. S. and Mattisen J. (2002) Equine seminal plasma protects the fertility of spermatozoa in an inflamed uterine environment. Theriogenology 58, 453-456

Vidament M., Dupere A. M., Julienne P., Evain A., Noue P. and Palmer $E$. (1997) Equine frozen semen freezability and fertility results. Theriogenology 48, 907-917

Watson E. D., Barbacini S., Berrocal B., Sheerin O., Marchi V., Zavaglia $G$. and Necchi D. (2001) Effect of insemination time of frozen semen on incidence of uterine fluid in mares. Theriogenology 56, 123-131

Dr. Sandro Barbacini

Select Breeders Services Europe

Via Argine Capolvogo 39

San Daniele Po

Cremona 26046

Italy

sandro@sbsitaliasrl.com 